\title{
Aberrant coagulation causes a hyper-inflammatory response in severe influenza pneumonia
}

\author{
Yan Yang $^{1}$ and Hong Tang ${ }^{1,2}$ \\ Influenza A virus (IAV) infects the respiratory tract in humans and causes significant morbidity and mortality \\ worldwide each year. Aggressive inflammation, known as a cytokine storm, is thought to cause most of the damage \\ in the lungs during IAV infection. Dysfunctional coagulation is a common complication in pathogenic influenza, \\ manifested by lung endothelial activation, vascular leak, disseminated intravascular coagulation and pulmonary \\ microembolism. Importantly, emerging evidence shows that an uncontrolled coagulation system, including both the \\ cellular (endothelial cells and platelets) and protein (coagulation factors, anticoagulants and fibrinolysis proteases) \\ components, contributes to the pathogenesis of influenza by augmenting viral replication and immune \\ pathogenesis. In this review, we focus on the underlying mechanisms of the dysfunctional coagulatory response in \\ the pathogenesis of IAV. \\ Cellular \& Molecular Immunology (2016) 13, 432-442; doi:10.1038/cmi.2016.1; published online 4 April 2016
}

Keywords: anticoagulant; coagulation; inflammation; influenza A virus

Influenza A virus (IAV) is a genus of the family Orthomyxoviridae that contains a negative-sense, single-stranded, segmented RNA genome and is categorized into subtypes based on the expression of hemagglutinin (HA; H1-H18) and neuraminidase (NA; N1-N11) on the surface of the viral envelope. ${ }^{1}$ Seasonal flu, which is caused by different subtypes of IAV, usually leads to the death of half a million people each year. Pandemic flu is caused by the genetic reassortment and transmission of IAV in the chain of wild birds/poultry/pigs and has become one of the most imminent dangers to human beings. ${ }^{2}$ Because of the lack of immune memory, these zoonotic viruses often cause high morbidity and mortality in infected people; for example, the notorious 1918 H1N1 pandemic killed up to 50 million people globally and the 2009 H1N1 pandemic had a death toll of up to 284500 people. ${ }^{3,4}$

Severe IAV, involving either seasonal or pandemic influenza virus, infects the upper respiratory tracts and induces acute respiratory distress syndrome (ARDS). ${ }^{5}$ Clinically, the characteristic alveolar changes of influenza virus pneumonia include capillary thrombosis, focal necrosis and hyperemia of the alveolar wall, inflammatory infiltration, the formation of hyaline membranes and pulmonary edema. ${ }^{6}$ Small vessel thrombosis, hemorrhage and diffuse alveolar damage are observed in severe influenza pneumonia, indicating disordered coagulation. ${ }^{6,7}$ Severe IAV also causes multiple organ dysfunction syndrome and disseminated intravascular coagulation (DIC). ${ }^{5,8,9}$

IAV primarily targets the airway and alveolar epithelial cells by binding to sialic acid residues through HA. The internalized viral RNA in the cytosol activates pattern recognition receptors, including Toll-like receptors (TLRs; primarily TLR3 and TLR7) and retinoic acid inducible gene-1 (RIG-I) to initiate the innate immune responses. Recognition of viral RNA by RIG-I and TLRs activates IRF3/7 to induce robust type I and III interferon (IFN- $\alpha / \beta$ and $-\lambda$ ) responses, which induce the transcription and release of hundreds of interferon-stimulated genes (ISGs) and trigger the activation of nuclear factor kappa B (NF- $\mathrm{BB})$ to induce the production of pro-inflammatory cytokines and chemokines (for example, interleukin (IL)-6, TNF- $\alpha$, MCP-1, MIP- $1 \alpha / \beta$ and RANTES). ${ }^{10,11}$ In addition, the viral RNA and proteins can also activate inflammasomes, resulting in the release of IL-1 $\beta$ and IL-18. ${ }^{12-14}$ IFNs and pro-inflammatory cytokines and chemokines are important for viral clearance and also induce the recruitment and activation of circulating neutrophils, monocytes and lymphocytes (natural killer (NK)

\footnotetext{
${ }^{1}$ Division of Viral Pathology, Wuhan Institute of Virology, Chinese Academy of Sciences, Wuhan 430071, China and ${ }^{2}$ Institute Pasteur of Shanghai, Chinese Academy of Sciences, 320 Yue-yang Road, Shanghai 200031, China

Correspondence: Professor H Tang, PhD, Institute Pasteur of Shanghai, Chinese Academy of Sciences, 320 Yue-yang Road, Shanghai 200031, China.

E-mail: tangh@wh.iov.cn or htang@ips.ac.cn

Received: 28 September 2015; Revised: 6 January 2016; Accepted: 6 January 2016; published online 4 April 2016
} 
cells, natural killer $\mathrm{T}$ cells and $\mathrm{T}$ cells) into the site of infection. ${ }^{15}$ In addition to further activating the innate immune response and priming the adaptive immune response to eradicate the virus, innate immune cells are often overactivated in IAV-induced ARDS and contribute to its high morbidity and mortality. ${ }^{16}$ The overproduction of pro-inflammatory cytokines and the overactivation of immune cells during IAV infection is known as a cytokine storm. ${ }^{17}$ Although the general concept of a cytokine storm is well known (reviewed in ref. 17), the precise constitution and molecular mechanisms of the IAVassociated hyper-inflammatory response in ARDS is largely unclear.

Emerging lines of evidence indicate that an aggressive immune response in severe influenza is augmented by dysfunctional coagulation, which is manifested by lung endothelial activation, vascular leak, disseminated intravascular coagulation and pulmonary microembolism. ${ }^{18-20}$ This review summarizes recent advances in understanding the hyper-inflammatory response that is caused by aberrant coagulation in IAV infection.

\section{OVERVIEW OF THE COAGULATION SYSTEM}

Coagulation is the formation of a blood clot. Coagulation is a highly ordered process that involves three components (endothelial cells, platelets and coagulation factors) in a sequential action of primary hemostasis, secondary hemostasis and fibrinolysis. ${ }^{21}$ Typically, coagulation is initiated by an injury to the vascular endothelial cells (ECs) (Figure 1b). Primary hemostasis is characterized by platelets that bind to injured and/or activated ECs and the immediate formation of a platelet plug (Figure 1c). Secondary coagulation has two separate initial pathways, the contact activation pathway (intrinsic pathway) and the tissue factor (TF) pathway (extrinsic pathway) (Figures $1 \mathrm{~d}$ and e). Both pathways result in the

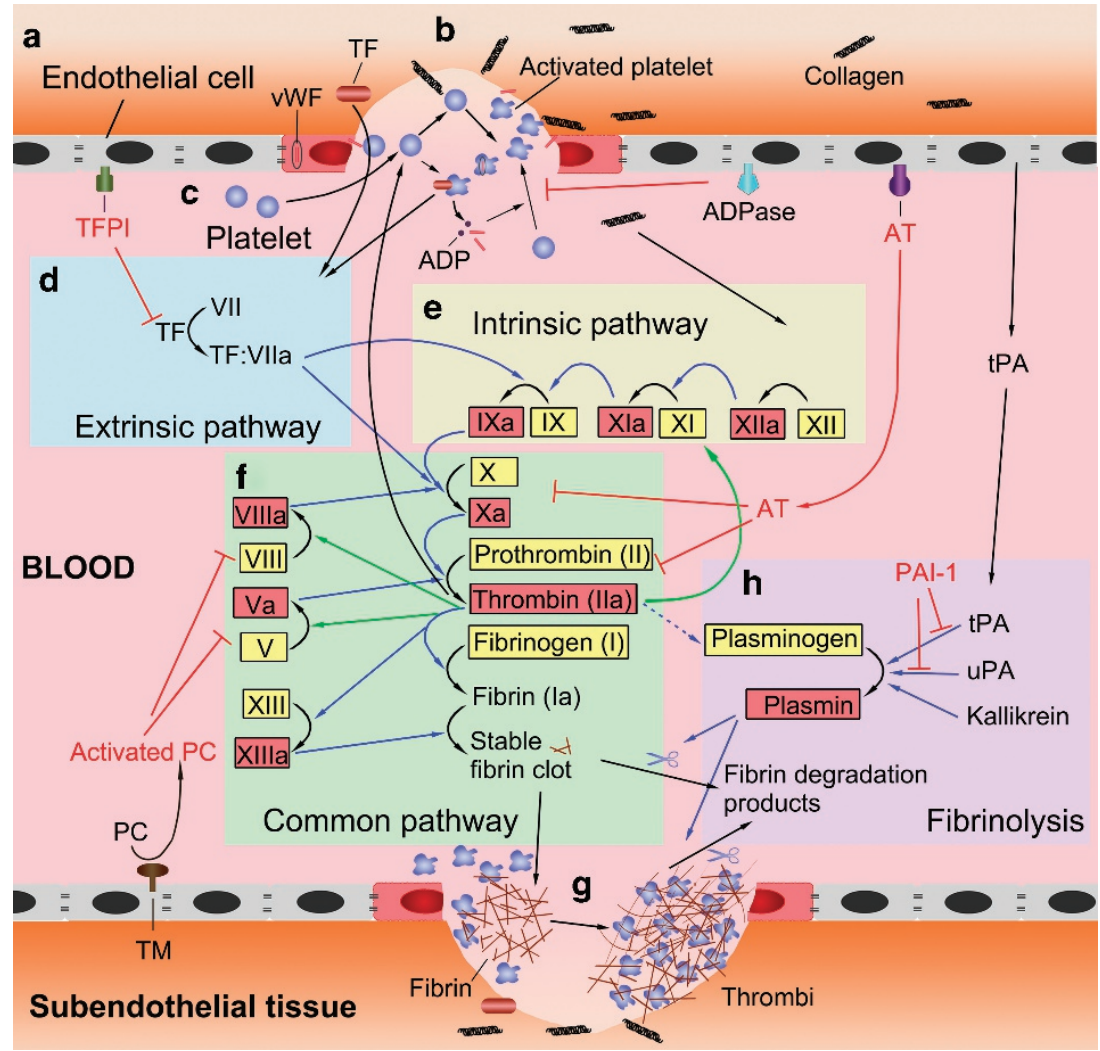

Figure 1 Cascades of the coagulation system. (a) Resting ECs provide natural anticoagulants (TM, AT and TFPI and ADPase) to inhibit coagulation and keep platelet activation and the coagulation cascade in check. (b) Coagulation is typically initiated by an injury to the vascular ECs, which results in the exposure of TF and collagen from the sub-endothelial tissue to the blood and the release of vWF. (c) Platelets are activated when they are exposed to TF, collagen and vWF. Activated platelets release a number of mediators, such as ADP and vWF stores within their granules, leading to further platelet recruitment, activation, aggregation and plug formation, which is a process termed primary hemostasis. (d) The interaction between TF and factor VII initiates the extrinsic pathway. (e) The exposure of collagen to blood starts the intrinsic pathway. (f) Both the extrinsic and intrinsic pathways result in the initiation of a common pathway, which contains the cascades involved in the production of activated Factor $\mathbf{X}$ and thrombin and the formation of fibrin strands. (g) Fibrin strands strengthen the platelet plug and lead to the formation of a stable platelet-fibrin clot. This process is termed secondary hemostasis. (h) Kallikrein, UPA or tPA activate plasminogen to plasmin, which then degrades and reabsorbs the polymerized fibrin strands. It is the eventual process of fibrinolysis that heals wounds. AT, antithrombin; ECs, endothelial cells; TF, tissue factor; TFPI, tissue factor pathway inhibitors; TM, thrombomodulin; tPA, tissue plasminogen activator; uPA, urokinase plasminogen activator; vWF, von Willebrand factor. 
production of factor $\mathrm{X}$, which induces thrombin and the formation of fibrin strands to strengthen the platelet plug and form a stable platelet-fibrin clot (Figures if and g). The coagulation process is tightly controlled by anticoagulants, which can limit the clot to avoid thrombus propagation, and fibrinolysis, which is responsible for the degradation of the platelet-fibrin clot as the wound heals (Figures la and h).

\section{COAGULATION DISORDER IS ASSOCIATED WITH INFLUENZA INFECTION}

Thrombosis, which often leads to hemorrhage, is a common clinical complication of severe influenza. Patients with a severe IAV infection, such as an H7N9 viral infection, ${ }^{6,22}$ often show typical alterations of coagulation, including hyperemia of the alveolar wall, pulmonary capillary and small vessel thrombosis, fibrin deposition and DIC, and hemorrhage. The coagulation abnormalities (coagulopathy) are characterized by a prolonged activated partial thromboplastin time, prothrombin time and thrombin time, and decreased platelet counts in the blood in patients infected with H7N9 $9^{23-25}$ or highly pathogenic H5N1. ${ }^{26,27}$ Both thrombotic and hemorrhagic complications were reported in the $2009 \mathrm{H} 1 \mathrm{~N} 1$ influenza ('swine flu'), such as microscopic thrombi, thromboemboli, pulmonary arterial thrombi and pulmonary hemorrhage with hemoptysis, hematemesis and petechial rash. ${ }^{28-31}$ Thus, an influenza virus infection results in disorders, including both overactivated coagulation that leads to uncontrolled thrombosis and coagulopathy that leads to pulmonary hemorrhage and edema.

The overactivation of coagulation by influenza exacerbates the risk of pulmonary and cardiac diseases. ${ }^{32-37}$ IAV infections also cause a transient increased risk of deep venous thrombosis and pulmonary embolism, ${ }^{32}$ acute coronary syndromes, ${ }^{37}$ acute cardiac injury, ${ }^{38}$ acute myocardial infarction (AMI) $)^{39,40}$ and other cardiovascular diseases. ${ }^{41,42}$ For example, H1N1 infection elevates the expression of genes that promote hemostasis and/or platelet aggregation and the signature platelet genes associated with AMI. ${ }^{43}$ Such acute thrombosis in an alreadydiseased coronary artery can cause a subcritical level of stenosis attributable to the development of acute coronary syndromes. ${ }^{37}$ Therefore, reducing the risk of infection by vaccination against influenza effectively reduces the risk of stroke hospitalization, ${ }^{44}$ AMI rates ${ }^{39}$ and other cardiovascular events, ${ }^{45}$ with beneficial cardiovascular outcomes $^{41}$ and increased survival among patients with acute heart failure. ${ }^{46}$ Clinical trials using oseltamivir (Tamiflu) have shown that a reduction in viral load is associated with a decrease in the incidence of cardiac disorders. ${ }^{47}$

Animal studies have partly explained the mechanism of activated coagulation by IAV infection. ${ }^{48,49}$ IAV activates coagulation by increasing thrombin generation, fibrin deposition and fibrinolysis in C57BL/6 mice. ${ }^{48} \mathrm{D}$-dimer (a circulating marker for enhanced coagulation and fibrinolysis) concentrations and von Willebrand factor (vWF) activity are both increased in ferrets after infection with seasonal, pandemic or highly pathogenic avian influenza (HPAI)-H5N1 viruses. ${ }^{49}$ The activation marker of coagulation thrombin-antithrombin complex is increased in both pandemic and HPAI-H5N1 virus-infected ferrets, while intra-capillary fibrin deposition is especially evident in HPAI-H5N1 infection. ${ }^{49}$

More importantly, such a pro-thrombotic state induced by influenza virus infection will inevitably downregulate the anticoagulant components and inhibit fibrinolysis. ${ }^{33,50-52}$ In turn, abnormal coagulation promotes hemorrhage and thrombosis, which is often associated with the overzealous inflammation observed during a severe IAV infection. ${ }^{20,33,53}$

\section{THE ABERRANT ACTIVATION OF ECS IS RESPONSIBLE FOR BOTH ABNORMAL COAGULATION AND HYPER- INFLAMMATION IN INFLUENZA}

Resting ECs provide a non-thrombogenic barrier that prevents the inappropriate activation of coagulation by producing numerous anticoagulant components and inhibiting platelet activation $^{54}$ (Figure 1a). Once activated or injured, ECs initiate coagulation by activating platelets and the expression of coagulation components, as well as by down-regulating physiological anticoagulant components and suppressing fibrinolytic activity ${ }^{5}$ (Figure 1b). At the same time, the activation of ECs can result in an increase in local blood circulation, localized plasma leakage and the recruitment and activation of leukocytes to promote inflammation. ${ }^{56,57}$ IAV can directly and/ or indirectly induce EC activation and vascular hyperpermeability (Figure 2a). Certain IAV subtypes, such as H3N2 and H5N1, may infect lung endothelial cells, which also express $\alpha 2$, 6-linked sialic acid and are adjacent to the primary target cells of the respiratory epithelia. Recognition of damage-associated molecular patterns, such as HMGB1 or oxidized phospholipids via TLR4, also activates ECs to drive lung injury. ${ }^{53,58,59}$ Direct stimulation of TLR3 by viral RNA results in the upregulation of $\mathrm{TF}$ and the downregulation of thrombomodulin in endothelial cells. ${ }^{60}$ Human IAV has been reported to induce pulmonary microvascular leakage through the degradation of the tight junction protein claudin-5. ${ }^{61}$ In vivo, D-dimer and tissue fibrin deposition are elevated. ${ }^{60}$

Inflammatory cytokines, produced by leukocytes, the lung epithelium and pulmonary endothelium, mainly contribute to endothelium dysfunction. Elevated TNF- $\alpha$ levels have been shown to induce EC apoptosis. TNF- $\alpha$, IL- $1 \beta$ and IL- 6 can upregulate trypsin in ECs, which results in the loss of zonula occludens-1 (ZO-1; a tight junction protein) and vascular hyperpermeability via protease-activated receptor-2 (PAR-2). ${ }^{62}$ Hypoxia, which is found in flu patients, contributes to EC activation to induce the release of pro-inflammatory IL-1, IL-6, platelet-activating factor (PAF), intercellular adhesion molecule 1 (ICAM-1), P-selectin and vWF. ${ }^{63}$ Thus, an IAV infection can induce pulmonary hemorrhage and alveolar edema through the activation and damage of ECs via several mechanisms, including direct damage, loss of tight junctions and hyperpermeability induced by inflammatory factors and the apoptosis of endothelial cells.

At the same time, the activation of and damage to ECs leads to the activation of the pro-coagulatory cascade. The expression of TF and vWF by activated ECs, the exposure of collagen to 


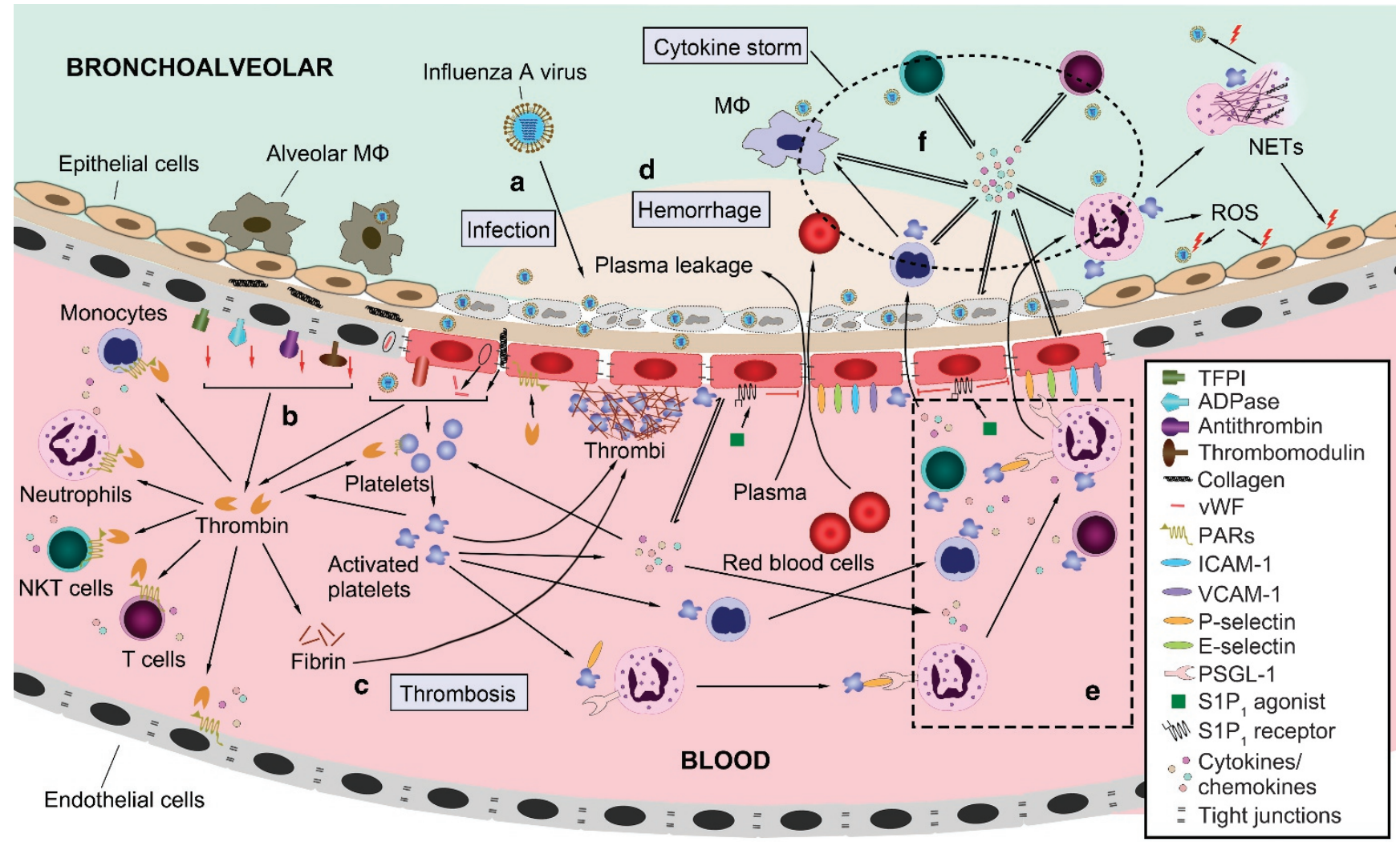

Figure 2 Interactions between coagulation and inflammation during IAV infection. (a) Airway and alveolar epithelial cells are the primary targets of IAV infection. IAV can directly infect ECs and/or indirectly induce EC activation and vascular hyperpermeability through PAMPs, DAMPs and inflammatory cytokines. (b) The activation of ECs induces a pro-thrombotic state by down-regulating the anticoagulant components (TM, AT, TFPI and ADPase), the expression of TF and vWF and the exposure of collagen to blood. Thrombin, FXa and FVIla, produced by the coagulation cascade, augment the inflammatory response by activating platelets, endothelial cells, monocytes, neutrophils, NKT and T cells through PARs. (c) Platelets are activated by exposure to thrombin, TF, collagen and vWF. Then, the coagulation cascades and thrombi formation are initiated. (d) The downregulation of tight junction protein on ECs and apoptosis of ECs induced by inflammatory cytokines lead to vascular hyperpermeability, which results in leakage of plasma and blood cells into the bronchoalveoli (hemorrhage). Decompensated thrombocytopenia is another reason for hemorrhage during an IAV infection. (e) Activated platelets act as pro-inflammatory cells by releasing inflammatory cytokines and promoting the activation, transmigration and cytokine release of neutrophils, T, B and NK cells, DC and monocytes. Activated platelets also modulate EC function to promote an inflammatory response. (f) The cytokine storm of overactivated neutrophils, monocytes and lymphocytes (NK cell, NKT cell and T cell), as well as the overproduction of inflammatory cytokines by these cells, contributes to the high morbidity and mortality during IAV infection. AT, antithrombin; DAMPs, damage-associated molecular patterns; DC, dendritic cell; EC, endothelial cell; IAV, influenza A virus; NK, natural killer; NKT, natural killer T cells; PAMPs, pathogen-associated molecular patterns; PAR, protease-activated receptor; TF, tissue factor; TFPI, tissue factor pathway inhibitor; TM, thrombomodulin; vWF, von Willebrand factor.

blood as a result of disruption of the endothelial barrier, and increased platelet binding to ECs induces platelet activation and aggregation, which then activates the extrinsic coagulation cascade (Figure 2b). ${ }^{21}$ EC activation reduces the expression or secretion of components of anticoagulation and fibrinolysis, and facilitates microthrombosis in the lung. ${ }^{18}$ Impaired coagulation then leads to DIC and triggers decompensated thrombocytopenia, which is induced by overactivation and excessive aggregation and passive exhaustion of platelets (discussed below). Pulmonary thrombosis results in passive congestion, limiting compensatory ventilation responses and then exacerbates vascular leakage and alveolar edema, contributing to widespread hemorrhaging, severe hypoxia, multiple organ failure and death during severe IAV infection (Figure 2d). ${ }^{64-66}$
Pulmonary ECs subsequently play a crucial role in the initiation and amplification of the cytokine storm during an IAV infection. By activating sphingosine-1-phosphate-1 $\left(\mathrm{S}_{1} \mathrm{P}_{1}\right)$ signaling in the pulmonary endothelium, $\mathrm{S}_{1} \mathrm{P}_{1}$ receptor agonists (CYM-5442 and RP-002) inhibit the cytokine storms and protect the host from pathogenic influenza virus challenge. ${ }^{53}$ Moreover, IL-1R signaling and MyD88/TRIF signaling are necessary for the early amplification of the cytokine storm, and $\mathrm{S}_{1} \mathrm{P}_{1}$ receptor agonist treatment blunts the cytokine storm mainly by inhibiting the MyD88 signaling pathway. ${ }^{67}$ Innate cytokine and chemokine production and innate immune cell infiltration are separable events, with the pulmonary endothelium at the center of both processes. ${ }^{53}$ The innate immune cell infiltration is regulated by ECs, which express adhesion 
molecules (P-selectin, E-selectin, ICAM-1 and VCAM-1) and facilitate the binding and migration of leukocytes during an influenza virus infection (Figure 2e). ${ }^{68,69}$ An activated ECplatelet-leukocyte interaction feeds forward to amplify the overall inflammatory response (Figure 2e). ${ }^{18}$ Thus, pulmonary ECs might be a potential therapeutic target because of their critical role in the amplification of the cytokine storm.

\section{MASSIVE INFILTRATION AND THE ACTIVATION OF PLATELETS CONTRIBUTES TO THE PATHOGENESIS OF INFLUENZA IN THE LUNGS}

The primary function of platelets is to sense the injured vessel endothelia and initiate blood clotting for hemostasis. ${ }^{70}$ Recent studies show that, in addition to their important roles in damage repair, platelets are also an integral part of the innate immune system as pro-inflammatory cells. ${ }^{71-73}$ After the activation of and damage to ECs, platelets are activated by numerous factors, including collagen, thromboxane A2, vWF, thrombin, ADP and pro-inflammatory cytokines or PAF (Figure 1c). ${ }^{52}$ Influenza virus $\mathrm{H} 1 \mathrm{~N} 1$ also activates platelets through FcyRIIA on platelets by the IgG-virus immune complex. ${ }^{52}$

Moreover, activated platelets release a number of mediators and cytokines from stores within their $\alpha$ - and dense-granules for further platelet recruitment, activation and aggregation (Figure 1c). Platelets are major pro-inflammatory cells under inflammatory conditions. ${ }^{71,74-77}$ Upon activation, platelets change from smooth discs to spiny spheres and rapidly release inflammatory and coagulatory mediators stored in their granules and express a number of receptors for adhesion and clotting molecules. ${ }^{77}$ The interaction of P-selectin on activated platelets and P-selectin glycoprotein ligand expressed on neutrophils leads to the activation of neutrophils in the circulation and the redistribution of Mac-1 and CXCR2, which guide neutrophil intravascular crawling and transmigration and the initiation of inflammation (Figure 2e). ${ }^{69}$ Such plateletneutrophil aggregates contribute to a variety of inflammatory settings, including acute lung injury, acute hepatic injury, sepsis and atherosclerosis. ${ }^{78-80}$ Platelet-neutrophil aggregation is also responsible for the generation of reactive oxygen species (ROS) by neutrophils, modulating the phagocytic capacity of neutrophils and the formation of neutrophil extracellular traps (webs of extracellular DNA and histones). ${ }^{79,80}$ Activated platelets also interact with T cells, B cells, NK cells, dendritic cells (DCs) and monocytes and induce their homing, activation and recruitment, and cytokine release (Figure 2e) ${ }^{81}$ More importantly, the cytokines and chemokines released from the activated platelets, including CD40L, IL-1 $\beta$, CCL5, CXCL4, CXCL7 and TGF- $\beta$, are profoundly involved in the modulation of endothelial cell function, leukocyte trafficking and immune response (Figure 2c). ${ }^{81}$ For example, CD40L, released from activated platelets, can activate CD40 on endothelial cells to upregulate ICAM-1, VCAM-1, E-selectin and P-selectin and to release IL-6, MCP-1, CCL2 and TF, thereby promoting leukocyte recruitment to lesions and immune activation. ${ }^{82-84}$
Massive infiltration of activated and aggregated platelets in the lungs may be associated with thrombocytopenia, which is often observed in highly pathogenic influenza virus infections but is rare for other human viruses, such as adenovirus, metapneumovirus, coronavirus or bocavirus infections. ${ }^{85}$ Thrombocytopenia has been observed in $73 \%$ of patients infected by avian origin H7N9 and is a risk factor for acute respiratory failure in $\mathrm{H} 1 \mathrm{~N} 1$ influenza. ${ }^{86-88}$ The overactivation of platelets by influenza viruses causes thrombosis in the lung, which can passively exhaust platelets, and lead to thrombocytopenia. ${ }^{20}$

Therefore, blockade of platelet overactivation and aggregation can reduce the severity of acute respiratory syndrome. ${ }^{20}$ For example, the administration of the PAR-1 antagonist SCH79797, which inhibits the activation of platelets induced by thrombin, decreases inflammation and improves survival after IAV infection in mice. ${ }^{89}$ A deficiency in the major platelet receptor glycoprotein IIIa (GPIIIa) or treatment with antiplatelet compounds (eptifibatide, MRS 2179, clopidogrel, acetylsalicylic acid/aspirin and ticlopidine) protects mice from lethal influenza virus infection. ${ }^{20,90}$ Aspirin also acts as an antiinfluenza virus agent in vitro by inhibiting pro-inflammatory NF- $\kappa \mathrm{B}$ activity and improving the influenza outcome in vivo. ${ }^{91}$ However, whether aspirin inhibits platelet activation in vivo is controversial because it may have increased the mortality of the 1918-1919 pandemic influenza ${ }^{92}$ and influenza virus infection in animal models. ${ }^{93}$ Larger scale clinical studies are needed to exclude strain variation in influenza viruses, various antipyretic regimes and models of meta-analysis. ${ }^{94,95}$ For example, treatment with aspirin and dicrofenac sodium aggravates the hematogenous spread of IAV to the central nervous system in chicken but does not affect transneural infection in mice. ${ }^{96}$ Interestingly, aspirin does not significantly increase mortality in an influenza B virus mouse model of Reye's syndrome. ${ }^{97}$ Aspirin and acetaminophen have the potential to exacerbate the consequences of influenza B virus infection in neonatal mice but not in weanling mice. ${ }^{98}$ Therefore, anti-platelet compounds should be explored as a potential treatment for influenza, but more studies are needed, and the data must be carefully interpreted.

\section{COAGULATION FACTORS AUGMENT THE INFLAMMATORY RESPONSE TO AN IAV INFECTION}

The plasma coagulation cascade is primarily initiated by TF during an influenza infection. ${ }^{19}$ Under physiological conditions, TF is present in the sub-endothelial tissue, fibroblasts and circulatory blood cells or ECs do not express TF (Figure 1a). Inflammation caused by IAV infection causes disruption of the vessel walls that exposes TF to the circulation. ${ }^{33,65}$ ECs and monocytes begin producing TF in response to various pro-inflammatory cytokines (such as TNF- $\alpha$, IL-1, IL-6, IL-8 and MCP-1) and pathogenassociated molecular pattern (such as viral RNA). ${ }^{60,99}$ The coagulation cascade is initiated quickly once TF has been exposed to the blood (Figure 1d). The activated coagulation cascade generates thrombin protease (factor IIa), which 
converts fibrinogen into fibrin (Figure 1f). Thrombin is involved in the feedback activation of coagulation by activating coagulation factors V, VIII, XI and XIII (Figures 1e and f). As one of the strongest platelet activators, thrombin also induces platelet aggregation and clot formation. ${ }^{100}$ Furthermore, fibrinogen and fibrin also activate macrophages and cytokine production through TLR4. ${ }^{101,102}$

In addition to their roles in coagulation, activated coagulatory factors, such as thrombin, FXa and FVIIa, also augment the initial inflammatory response. Treatment with a recombinant inhibitor of the FVIIa/TF complex attenuates the pro-inflammatory response and prolongs survival rates in a rhesus monkey model of Ebola hemorrhagic fever. ${ }^{103}$ The proinflammatory function of coagulation factors is mediated through their activation of PARs (PAR-1, $-2,-3$ and -4 ), which are mainly expressed in platelets and other cell types, including ECs, macrophages, mast cells, eosinophils, myocytes and gastrointestinal and bronchial epithelial cells. ${ }^{19,89,104}$ PAR-1, -3 and -4 are activated by thrombin, whereas PAR-2 is activated by FVIIa and FXa but not by thrombin. PAR-1 is also responsible for FXa signaling. ${ }^{19}$ PAR signaling activates ECs, platelets and leukocytes to express pro-inflammatory cytokines and chemokines, and increases the permeability of ECs and the adhesion and chemotaxis of leukocytes (Figure 2b). ${ }^{19}$ The TF/thrombin/PAR-1 pathway promotes the deleterious innate inflammatory response to an influenza virus infection in mice. ${ }^{89,104}$ PAR-2 plays both a protective and a pathogenic role in response to an H1N1 infection. ${ }^{105,106}$ The activation of PAR-4 exacerbates acute lung injury, inflammation and death through platelet activation and a PAR-4 antagonist (pepducin p4pal-10) protects mice during influenza virus infection. ${ }^{20}$ Taken together, these results suggest that coagulation factors mainly play pathogenic roles through PAR-1 and PAR-4, which may serve as therapeutic targets against IAV infection.

\section{THE HOMEOSTASIS OF THE INFLAMMATORY RESPONSE IS MAINTAINED BY INTRINSIC ANTI-COAGULANT COMPONENTS IN IAV INFECTION}

To keep the platelet activation and coagulation cascade in check, coagulation is well regulated by three major anticoagulant mechanisms, which are protein $\mathrm{C}$ (PC), antithrombin (AT) and the tissue factor pathway inhibitor (TFPI; Figure 1a). ${ }^{107} \mathrm{~A}$ deficiency in anticoagulants may result in acquired thrombophilia, a condition in which there is an increased tendency to form blood clots.

PC, a major endogenous anticoagulant, is activated by thrombin. ${ }^{108}$ Activated PC cleaves the activated FVa and FVIIIa to inhibit the coagulation cascades. ${ }^{108}$ In addition to its anticoagulatory role, activated PC also exerts anti-inflammatory activity by inhibiting pro-inflammatory cytokine production and leukocyte infiltration. ${ }^{109-113}$ Reduced PC, on the other hand, increases the generation of thrombin during an influenza virus infection. ${ }^{48}$ However, because of the complex network that regulates coagulation, contradictory effects of PC are often observed in lethal H1N1 influenza in mice: while it can inhibit inflammation and pulmonary coagulopathy, it also facilitates neutrophil influx and protein leakage into the bronchoalveolar. ${ }^{14,115}$ Additionally, anti-PC antibody treatment results in delayed mortality, ${ }^{114}$ but recombinant activated PC treatment does not affect the outcome. ${ }^{115}$ Therefore, the function of PC during influenza virus infection remains uncertain.

AT (also known as antithrombin III) is a serine protease inhibitor produced by the liver. AT functions as an anticoagulant by inhibiting thrombin, as well as FXa, FIXa, FIa and FXIIa, and its activity is increased by heparin. ${ }^{116}$ By binding to thrombin, AT directly suppresses the activation of pro-inflammatory cells (leukocytes, ECs and platelets). ${ }^{117}$ Furthermore, AT inhibits leukocyte rolling, adhesion and activation directly by binding to receptors on the leukocyte or indirectly by endothelial cell-released PGI(2) that tethers AT to cell surface glycosaminoglycan. ${ }^{118,119}$ Of further interest, AT possesses antiviral activity against HIV, ${ }^{120,121}$ HSV $^{122,123}$ and HCV. ${ }^{124}$ The antiviral activities of AT reside in its serine protease inhibitor activity against the hemagglutinin of influenza A virus H1N1 in vitro and in vivo. ${ }^{125}$ In line with this, several proteases (Gzma, Tmprss4, Elane, Ctrl, Gzmc and Gzmb) are upregulated in the lung after mice are infected with the H1N1 virus, and treatment with serine protease inhibitors protects mice from the fatal infection. ${ }^{126}$

TFPI is another serine protease inhibitor present in endothelia and platelets. By targeting the TF-FVIIa complex, it inhibits coagulation cascades and modulates platelet pro-coagulant activity. ${ }^{127}$ However, the function of TFPI in inflammation or viral infection remains largely unknown.

ADAMTS13 is an anticoagulant protease that cleaves vWF. It is produced in liver stellate cells and endothelial cells and is also present in platelets. Systemic inflammation reduces ADAMTS13 activity, ${ }^{128}$ resulting in the formation of highmolecular weight vWF multimers and increased platelet activation. ${ }^{129}$ Acute IAV infections reduce the level of ADAMTS13 and elevate the level of anti-ADAMTS13 antibodies, which are associated with thrombotic thrombocytopenic purpura. ${ }^{35,36}$ A markedly high ratio of vWF to ADAMTS13 in the circulation has been found in H1N1 influenza patients with thrombotic microangiopathy. ${ }^{51}$ The decreased level of ADAMTS13 might result from the influenza virus-induced cytokine storm. However, whether ADAMTS13 takes part in the initiation and amplification of the inflammatory response is unknown.

\section{FIBRINOLYSIS IS INVOLVED IN BOTH LUNG INFLAMMATION AND THE INFLUENZA A VIRUS LIFE CYCLE}

Coagulation is resolved by fibrinolysis, a process that involves a distinct enzymatic cascade. In the physiological state, fibrinolysis is initiated by three serine proteases: tissue plasminogen activator (tPA), urokinase plasminogen activator (uPA) and kallikrein (Figure 1h). ${ }^{130} \mathrm{uPA}$ and tPA initiate the conversion of the zymogen plasminogen to the serine proteinase plasmin, which dissolves the polymerized fibrin strands. Fibrinolysis is 
regulated by other molecules, including $\alpha 2$-antiplasmin, $\alpha 2$ macroglobulin, plasminogen activator inhibitor-1 (PAI-1) and thrombin-activatable fibrinolysis inhibitor. ${ }^{131}$ In addition to its fibrinolysis activity, plasmin plays a critical role in a variety of processes, including inflammation. ${ }^{132,133}$ Plasminogen binds to different receptors on monocytes, macrophages, DCs and other immune cells and generates plasmin, which is responsible for the migration and recruitment of inflammatory immune cells to lesions and subsequently stimulates the production of proinflammatory cytokines and chemokines and ROS. ${ }^{132}$ In fact, excessive activation of plasmin exacerbates the pathogenesis of different inflammatory diseases. ${ }^{132}$

Plasminogen and plasmin play critical roles in the infectivity of influenza viruses. The proteolytic cleavage of HA by trypsinlike proteases in the respiratory tract can process the HA precursor protein into two disulfide bond-linked subunits, HA1 and HA2. This is an essential step in the life cycle and is required for IAV infectivity. ${ }^{134}$ Influenza viruses use the conversion of plasminogen into plasmin, and the latter possesses a trypsin-like protease activity to cleave HA (Figure 3b). ${ }^{135,136}$ Moreover, mini-plasmin, which is generated by the sequential processing of plasminogen by a plasminogen activator and elastases, has been found in the epithelial cells of the bronchioles and is reported to process HA. ${ }^{137}$ The accumulation of mini-plasmin in the cerebral capillaries has

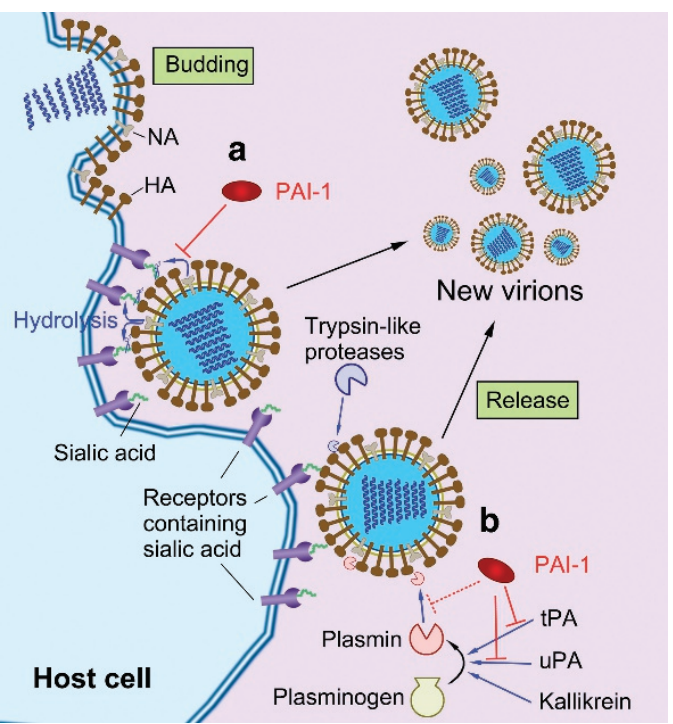

Figure 3 The role of the fibrinolytic components in the IAV life cycle. (a) The release of influenza virus particles from the host cell is mediated by NA through the cleavage of sialic acid from glycoproteins. PAI-1 inhibits viral glycoprotein cleavage, reducing the spread of the virus from the host cell to uninfected surrounding cells. (b) HA of the IAV is typically cleaved by trypsin-like proteases to gain viral fusion capacity. Certain influenza viruses can hijack plasmin for cleaving their HA to increase their viral infectivity and spread. PAI-1 acts as an anti-influenza molecule through the inhibition of HA cleavage by plasmin, as PAI-1 is the main inhibitor of the plasminogen activators. HA, hemagglutinin; IAV, influenza A virus; NA, neuraminidase; PAI, plasminogen activator inhibitor-1. also been implicated in influenza encephalitis. ${ }^{138,139}$ Therefore, plasminogen-dependent cleavage of HA is used by influenza viruses to increase their replication rates and infectivity (Figure $3 \mathrm{~b}$ ). On the other hand, the binding of NA of the influenza virus A/WSN/33 to plasminogen helps to sequestrate plasminogen on the cell surface and increases the cleavage of HA. This further helps in the dissemination of the virus and the efficient replication of IAV in the brains of mice. ${ }^{135,136}$ Binding of plasminogen to NA seems to rely on the unique sequence motif of the WSN strain. ${ }^{135}$ The activation of plasminogen also helps with the replication of other influenza virus strains in an NA-independent fashion. In this case, annexin II of the host cell binds to plasminogen and activates HA cleavage. ${ }^{134,140,141}$ Moreover, viral HA itself seems to be able to recruit plasminogen for HA cleavage. ${ }^{142}$ Bacterial staphylokinase can activate plasminogen to plasmin and thereby induce cleavage of HA of the MS96 (H9N2) virus. This mechanism may partly explain why bacterial infection can enhance influenza infectivity. ${ }^{143}$

Plasminogen not only facilitates the infection of IAV but also contributes to the pathogenicity of the viral infection. ${ }^{144}$ Fibrinolysis (fibrinogen degradation) is one of the underlying mechanisms of plasminogen-driven lung inflammation and mortality. A blockade of plasminogen fibrinolysis by 6aminohexanoic acid (6-AHA) treatment, for example, protects mice from influenza virus lethality. ${ }^{144}$ Increased vascular permeability, induced by plasminogen, helps in the recruitment of inflammatory cells to the site of IAV infection and also contributes to the inflammation response. ${ }^{144}$ Plasminogen might also interact with PAR-1 to decrease survival and increase lung inflammation after an influenza infection. ${ }^{89}$

PAI-1, encoded by the SERPINE1 gene, is a serine protease inhibitor that inhibits the activation of tPA and uPA and, hence, fibrinolysis (Figure 1h). ${ }^{145}$ Recently, PAI-1 was identified as an unconventional ISG that targets extracellular airway proteases to inhibit viral glycoprotein cleavage and reduce the infectivity of progeny viruses in vitro and in vivo (Figure 3a). ${ }^{146}$ Influenza virus infection can increase the production of PAI-1 from ECs and airway epithelial cells, which inhibits the spread of the IAV. ${ }^{146,147}$ Increased PAI-1 expression may not protect hosts against an IAV infection under certain circumstances; for example, passive cigarette smoke exposure can induce PAI-1 expression, but it promotes alveolar epithelial cell apoptosis and exacerbates lung inflammation after an IAV infection. ${ }^{148}$

\section{BACTERIAL SUPERINFECTION AFFECTS INFLUENZA PATHOGENESIS THROUGH THE HYPER-ACTIVATION OF COAGULATION}

Bacterial superinfection during influenza, primarily by Streptococcus pneumoniae, often results in hospitalization and even the death of patients. ${ }^{149-151}$ IAV-S. pneumoniae co-infection in mice causes a markedly more severe disease and hyperactivation of coagulation compared with IAV infection alone ${ }^{64}$ Widespread pulmonary thrombosis and the extensive expression of TF on the endothelial, epithelial and immune cells is found in the lung sections of $S$. pneumoniae-positive 
$1918 \mathrm{H} 1 \mathrm{~N} 1$ autopsies and co-infected mice. ${ }^{64}$ A secondary S. pneumoniae infection is held accountable for the overexpression of TF, the initiation of the coagulation cascade and thrombus formation, which contribute to severe hypoxia and death. ${ }^{64}$

Unlike the pathogenic bacterial superinfection, the colonization of commensal bacteria or pretreatment with probiotic bacteria can dampen influenza-mediated acute lung injury. Staphylococcus aureus, one of the most common commensal bacterium colonized in the airways, induces the polarization of M2 alveolar macrophages and inhibits the lethal inflammatory response to an IAV infection. ${ }^{152}$ Furthermore, both oral and nasal pretreatment with the probiotic lactic acid bacteria strains (Lactobacillus rhamnosus CRL1505) protects mice from PR8 lethality. ${ }^{153,154}$ Pretreatment with L. rhamnosus significantly reduces coagulatory activation mainly through the downregulation of TF and the restoration of thrombomodulin levels. ${ }^{154}$ Taken together, these studies show that bacteria in the airways affect the outcome of IAV pneumonia, and precise targeting of the bacteria should be considered in the treatment of influenza.

\section{CONCLUSION}

Influenza virus infection causes excessive activation of ECs and platelets, which triggers a coagulation cascade with concurrently impaired anti-coagulatory and fibrinolytic signaling. Such a pro-coagulant state can cause hemorrhagic fever and is often associated with ARDS in severe flu patients. The aberrant coagulation system contributes to the severity of influenza at multiple levels. The activated ECs and platelets first produce pro-inflammatory cytokines and chemokines that enhance inflammatory cell infiltration and increase vascular permeability. Platelets are further activated under these circumstances. Second, coagulation factors are activated, which further augment the inflammation via PARs on ECs, platelets and leukocytes. Third, the expression of anticoagulant components decreases as the ECs are activated. And last, fibrinolytic proteases (such as plasmin) are activated by the upregulated coagulation, which has been hijacked by the influenza virus for viral replication and infectivity.

Understanding the cellular and molecular events of coagulation will contribute to the development of more precise therapeutics against IAV infections. Drugs that target endothelial cell activation $\left(\mathrm{S}_{1} \mathrm{P}_{1}\right.$ agonists $\mathrm{CYM}-5442$ and RP-002), anti-platelet agents (eptifibatide, aspirin, MRS 2179 and clopidogrel), anticoagulants (recombinant activated PC and Ancrod) and protease inhibitors (6-AHA, PAI-1 and aprotinin ${ }^{155}$ ) effectively hamper pathogenic IAV infection in mice. Nevertheless, the detailed mechanisms of how coagulation contributes to the pathogenesis of severe influenza, especially in humans, remains to be investigated. A better understanding of coagulatory homeostasis would definitely benefit the development of more precise treatments for epidemic and pandemic influenza.

\section{CONFLICT OF INTEREST}

The authors declare no conflict of interest.

\section{ACKNOWLEDGEMENTS}

This work is supported by grants from the National Natural Sciences Foundation of China (NSFC) to HT (No. 81590764) and YY (No. 31400755).

1 Tong S, Zhu X, Li Y, Shi M, Zhang J, Bourgeois M et al. New world bats harbor diverse influenza A viruses. PLoS Pathog 2013; 9 . e1003657.

2 Kuiken T, Riteau B, Fouchier RA, Rimmelzwaan GF. Pathogenesis of influenza virus infections: the good, the bad and the ugly. Curr Opin Virol 2012; 2: 276-286.

3 Wu A, Su C, Wang D, Peng Y, Liu M, Hua S et al. Sequential reassortments underlie diverse influenza H7N9 genotypes in China. Cell Host Microbe 2013; 14: 446-452.

4 Gao R, Cao B, Hu Y, Feng Z, Wang D, Hu W et al. Human infection with a novel avian-origin influenza A (H7N9) virus. New Engl J Med 2013; 368: 1888-1897.

5 Short KR, Kroeze EJ, Fouchier RA, Kuiken T. Pathogenesis of influenza-induced acute respiratory distress syndrome. Lancet Infect Dis 2014; 14: 57-69.

6 Taubenberger JK, Morens DM. The pathology of influenza virus infections. Annu Rev Pathol 2008; 3: 499-522.

7 Rosen DG, Lopez AE, Anzalone ML, Wolf DA, Derrick SM, Florez LF et al. Postmortem findings in eight cases of influenza $\mathrm{A} / \mathrm{H} 1 \mathrm{~N} 1$. Mod Pathol 2010; 23: 1449-1457.

8 Davison AM, Thomson D, Robson JS. Intravascular coagulation complicating influenza A virus infection. $B r$ Med J 1973; 1: 654-655.

9 Watanabe T. Renal complications of seasonal and pandemic influenza A virus infections. Eur J Pediatr 2013; 172: 15-22.

10 Pang IK, Pillai PS, Iwasaki A. Efficient influenza A virus replication in the respiratory tract requires signals from TLR7 and RIG-I. Proc Natl Acad Sci USA 2013; 110: 13910-13915.

11 Gao R, Bhatnagar J, Blau DM, Greer P, Rollin DC, Denison AM et al. Cytokine and chemokine profiles in lung tissues from fatal cases of 2009 pandemic influenza A (H1N1): role of the host immune response in pathogenesis. Am J Pathol 2013; 183: 1258-1268.

12 McAuley JL, Tate MD, MacKenzie-Kludas CJ, Pinar A, Zeng W, Stutz A et al. Activation of the NLRP3 inflammasome by IAV virulence protein PB1-F2 contributes to severe pathophysiology and disease. PLoS Pathog 2013; 9: e1003392.

13 Ichinohe T, Pang IK, Iwasaki A. Influenza virus activates inflammasomes via its intracellular M2 ion channel. Nat Immunol 2010; 11: 404-410.

14 Lupfer C, Thomas PG, Anand PK, Vogel P, Milasta S, Martinez J et al. Receptor interacting protein kinase 2-mediated mitophagy regulates inflammasome activation during virus infection. Nat Immunol 2013; 14: $480-488$

15 Iwasaki A, Pillai PS. Innate immunity to influenza virus infection. Nat Rev Immunol 2014; 14: 315-328.

16 Brandes M, Klauschen F, Kuchen S, Germain RN. A systems analysis identifies a feedforward inflammatory circuit leading to lethal influenza infection. Cell 2013; 154: 197-212.

17 Liu Q, Zhou YH, Yang ZQ. The cytokine storm of severe influenza and development of immunomodulatory therapy. Cell Mol Immunol 2016; 13: 3-10.

18 Armstrong SM, Darwish I, Lee WL. Endothelial activation and dysfunction in the pathogenesis of influenza $A$ virus infection. Virulence 2013; 4: 537-542.

19 Antoniak S, Mackman N. Multiple roles of the coagulation protease cascade during virus infection. Blood 2014; 123: 2605-2613.

20 Le VB, Schneider JG, Boergeling Y, Berri F, Ducatez M, Guerin JL et al. Platelet activation and aggregation promote lung inflammation and influenza virus pathogenesis. Am J Respir Crit Care Med 2015; 191: 804-819.

21 Palta S, Saroa R, Palta A. Overview of the coagulation system. Indian J Anaesth 2014; 58: 515-523.

22 To KK, Song W, Lau SY, Que TL, Lung DC, Hung IF et al. Unique reassortant of influenza $A(H 7 N 9)$ virus associated with severe disease emerging in Hong Kong. J Infect 2014; 69: 60-68. 
23 Chen E, Wang F, Lv H, Zhang Y, Ding H, Liu S et al. The first avian influenza A (H7N9) viral infection in humans in Zhejiang Province, China: a death report. Front Med 2013; 7: 333-344.

24 Chen Y, Liang W, Yang S, Wu N, Gao H, Sheng J et al. Human infections with the emerging avian influenza A H7N9 virus from wet market poultry: clinical analysis and characterisation of viral genome. Lancet 2013; 381: 1916-1925.

25 Lu S, Li T, Xi X, Chen Q, Liu X, Zhang B et al. Prognosis of 18 H7N9 avian influenza patients in Shanghai. PLoS One 2014; 9: e88728.

26 Wiwanitkit V. Hemostatic disorders in bird flu infection. Blood Coagul Fibrinolysis 2008; 19: 5-6.

27 Claas EC, Osterhaus AD, van Beek R, De Jong JC, Rimmelzwaan GF, Senne DA et al. Human influenza A H5N1 virus related to a highly pathogenic avian influenza virus. Lancet 1998; 351: 472-477.

28 Harms PW, Schmidt LA, Smith LB, Newton DW, Pletneva MA, Walters LL et al. Autopsy findings in eight patients with fatal H1N1 influenza. Am J Clin Pathol 2010; 134: 27-35.

29 Soto-Abraham MV, Soriano-Rosas J, Diaz-Quinonez A, Silva-Pereyra J, Vazquez-Hernandez P, Torres-Lopez $O$ et al. Pathological changes associated with the 2009 H1N1 virus. New Engl J Med 2009; 361: 2001-2003.

30 Gilbert CR, Vipul K, Baram M. Novel H1N1 influenza A viral infection complicated by alveolar hemorrhage. Respir Care 2010; 55: 623-625.

31 Mauad T, Hajjar LA, Callegari GD, da Silva LF, Schout D, Galas FR et al. Lung pathology in fatal novel human influenza A (H1N1) infection. Am J Respir Crit Care Med 2010; 181: 72-79.

32 Smeeth L, Cook C, Thomas S, Hall AJ, Hubbard R, Vallance P. Risk of deep vein thrombosis and pulmonary embolism after acute infection in a community setting. Lancet 2006; 367: 1075-1079.

33 Marsden PA. Inflammation and coagulation in the cardiovascular system: the contribution of influenza. Circ Res 2006; 99: $1152-1153$.

34 Rothberg MB, Haessler SD, Brown RB. Complications of viral influenza. Am J Med 2008; 121: 258-264.

35 Kosugi N, Tsurutani $Y$, Isonishi A, Hori $Y$, Matsumoto M, Fujimura Y. Influenza A infection triggers thrombotic thrombocytopenic purpura by producing the anti-ADAMTS13 IgG inhibitor. Intern Med 2010; 49: 689-693.

36 Jonsson MK, Hammenfors D, Oppegaard O, Bruserud O, Kittang AO. A 35-year-old woman with influenza A-associated thrombotic thrombocytopenic purpura. Blood Coagul Fibrinolysis 2015; 26: 469-472.

37 Corrales-Medina VF, Madjid M, Musher DM. Role of acute infection in triggering acute coronary syndromes. Lancet Infect Dis 2010; 10: 83-92.

38 Ludwig A, Lucero-Obusan C, Schirmer P, Winston C, Holodniy M. Acute cardiac injury events $\leqslant 30$ days after laboratory-confirmed influenza virus infection among U.S. veterans, 2010-2012. BMC Cardiovasc Disord 2015; 15: 109.

39 Barnes M, Heywood AE, Mahimbo A, Rahman B, Newall AT, Macintyre CR. Acute myocardial infarction and influenza: a metaanalysis of case-control studies. Heart 2015; 101: 1738-1747.

40 Warren-Gash C, Smeeth L, Hayward AC. Influenza as a trigger for acute myocardial infarction or death from cardiovascular disease: a systematic review. Lancet Infect Dis 2009; 9: 601-610.

41 Clar C, Oseni Z, Flowers N, Keshtkar-Jahromi M, Rees K. Influenza vaccines for preventing cardiovascular disease. Cochrane Database Syst Rev 2015; 5: CD005050.

42 Kwok CS, Aslam S, Kontopantelis E, Myint PK, Zaman MJ, Buchan I et al. Influenza, influenza-like symptoms and their association with cardiovascular risks: a systematic review and meta-analysis of observational studies. Int J Clin Pract 2015; 69: 928-937.

43 Rose JJ, Voora D, Cyr DD, Lucas JE, Zaas AK, Woods CW et al. Gene expression profiles link respiratory viral infection, platelet response to aspirin, and acute myocardial infarction. PLOS One 2015; 10: e0132259.

44 Lin HC, Chiu HF, Ho SC, Yang CY. Association of influenza vaccination and reduced risk of stroke hospitalization among the elderly: a population-based case-control study. Int J Environ Res Public Health 2014; 11: 3639-3649.

45 Granwehr B. ACP Journal Club. Review: influenza vaccination reduces cardiovascular events in adults. Ann Intern Med 2014; 160: JC2.

46 Kopel E, Klempfner R, Goldenberg I. Influenza vaccine and survival in acute heart failure. Eur J Heart Fail 2014; 16: 264-270.
47 Dobson J, Whitley RJ, Pocock S, Monto AS. Oseltamivir treatment for influenza in adults: a meta-analysis of randomised controlled trials. Lancet 2015; 385: 1729-1737.

48 Keller TT, van der Sluijs KF, de Kruif MD, Gerdes VE, Meijers JC, Florquin $\mathrm{S}$ et al. Effects on coagulation and fibrinolysis induced by influenza in mice with a reduced capacity to generate activated protein $\mathrm{C}$ and a deficiency in plasminogen activator inhibitor type 1 . Circ Res 2006; 99: 1261-1269.

49 Goeijenbier M, van Gorp EC, Van den Brand JM, Stittelaar K, Bakhtiari K, Roelofs JJ et al. Activation of coagulation and tissue fibrin deposition in experimental influenza in ferrets. BMC Microbiol 2014; 14: 134.

50 Herold S, Becker C, Ridge KM, Budinger GR. Influenza virus-induced lung injury: pathogenesis and implications for treatment. Eur Respir J 2015; 45: 1463-1478.

51 Akiyama R, Komori I, Hiramoto R, Isonishi A, Matsumoto M, Fujimura Y. H1N1 influenza (swine flu)-associated thrombotic microangiopathy with a markedly high plasma ratio of von Willebrand factor to ADAMTS13. Intern Med 2011; 50: 643-647.

52 Boilard E, Pare G, Rousseau M, Cloutier N, Dubuc I, Levesque T et al. Influenza virus H1N1 activates platelets through FcgammaRIIA signaling and thrombin generation. Blood 2014; 123: 2854-2863.

53 Teijaro JR, Walsh KB, Cahalan S, Fremgen DM, Roberts E, Scott F et al. Endothelial cells are central orchestrators of cytokine amplification during influenza virus infection. Cell 2011; 146: 980-991.

54 van Hinsbergh VW. Endothelium - role in regulation of coagulation and inflammation. Semin Immunopathol 2012; 34: 93-106.

55 Vallet B, Wiel E. Endothelial cell dysfunction and coagulation. Crit Care Med 2001; 29(7 Suppl): S36-S41.

56 Pober JS, Sessa WC. Evolving functions of endothelial cells in inflammation. Nat Rev Immunol 2007; 7: 803-815.

57 Pate M, Damarla V, Chi DS, Negi S, Krishnaswamy G. Endothelial cell biology: role in the inflammatory response. Adv Clin Chem 2010; 52: 109-130.

58 Imai Y, Kuba K, Neely GG, Yaghubian-Malhami R, Perkmann T, van Loo $\mathrm{G}$ et al. Identification of oxidative stress and Toll-like receptor 4 signaling as a key pathway of acute lung injury. Cell 2008; 133 : 235-249.

59 Tsai SY, Segovia JA, Chang TH, Morris IR, Berton MT, Tessier PA et al. DAMP molecule S100A9 acts as a molecular pattern to enhance inflammation during influenza $A$ virus infection: role of DDX21-TRIF-TLR4-MyD88 pathway. PLoS Pathog 2014; 10: e1003848.

60 Shibamiya A, Hersemeyer K, Schmidt Woll T, Sedding D, Daniel JM, Bauer $\mathrm{S}$ et al. A key role for Toll-like receptor-3 in disrupting the hemostasis balance on endothelial cells. Blood 2009; 113: 714-722.

61 Armstrong SM, Wang C, Tigdi J, Si X, Dumpit C, Charles S et al. Influenza infects lung microvascular endothelium leading to microvascular leak: role of apoptosis and claudin-5. PLoS One 2012; 7: e47323.

62 Wang S, Le TQ, Kurihara N, Chida J, Cisse Y, Yano M et al. Influenza virus-cytokine-protease cycle in the pathogenesis of vascular hyperpermeability in severe influenza. J Infect Dis 2010; 202: 991-1001.

63 Pinsky DJ, Naka Y, Liao H, Oz MC, Wagner DD, Mayadas TN et al. Hypoxia-induced exocytosis of endothelial cell Weibel-Palade bodies. A mechanism for rapid neutrophil recruitment after cardiac preservation. J Clin Invest 1996; 97: 493-500.

64 Walters KA, D'Agnillo F, Sheng ZM, Kindrachuk J, Schwartzman LM, Kuestner RE et al. 1918 pandemic influenza virus and Streptococcus pneumoniae co-infection results in activation of coagulation and widespread pulmonary thrombosis in mice and humans. J Pathol 2016; 238: 85-97.

65 Visseren FL, Bouwman JJ, Bouter KP, Diepersloot RJ, de Groot PH, Erkelens DW. Procoagulant activity of endothelial cells after infection with respiratory viruses. Thromb Haemost 2000; 84: 319-324.

66 Goeijenbier M, van Wissen M, van de Weg C, Jong E, Gerdes VE, Meijers JC et al. Review: viral infections and mechanisms of thrombosis and bleeding. J Med Virol 2012; 84: 1680-1696.

67 Teijaro JR, Walsh KB, Rice S, Rosen H, Oldstone MB. Mapping the innate signaling cascade essential for cytokine storm during influenza virus infection. Proc Natl Acad Sci USA 2014; 111: 3799-3804.

68 Perrone LA, Plowden JK, Garcia-Sastre A, Katz JM, Tumpey TM. H5N1 and 1918 pandemic influenza virus infection results in early 
and excessive infiltration of macrophages and neutrophils in the lungs of mice. PLoS Pathog 2008; 4: e1000115.

69 Sreeramkumar V, Adrover JM, Ballesteros I, Cuartero MI, Rossaint J, Bilbao I et al. Neutrophils scan for activated platelets to initiate inflammation. Science 2014; 346: 1234-1238.

70 Semple JW, Italiano JE Jr., Freedman J. Platelets and the immune continuum. Nat Rev Immunol 2011; 11: 264-274.

71 Tamagawa-Mineoka R. Important roles of platelets as immune cells in the skin. J Dermatol Sci 2015; 77: 93-101.

72 Vieira-de-Abreu A, Campbell RA, Weyrich AS, Zimmerman GA. Platelets: versatile effector cells in hemostasis, inflammation, and the immune continuum. Semin Immunopathol 2012; 34: 5-30.

73 Esmon CT, Xu J, Lupu F. Innate immunity and coagulation. J Thromb Haemost 2011; 9(Suppl 1): 182-188.

74 Stokes KY, Granger DN. Platelets: a critical link between inflammation and microvascular dysfunction. J Physiol 2012; 590: 1023-1034.

75 Klinger $\mathrm{MH}$, Jelkmann $\mathrm{W}$. Role of blood platelets in infection and inflammation. J Interferon Cytokine Res 2002; 22: 913-922.

76 Gawaz M, Langer H, May AE. Platelets in inflammation and atherogenesis. J Clin Invest 2005; 115: 3378-3384.

77 Morrell CN, Aggrey AA, Chapman LM, Modjeski KL. Emerging roles for platelets as immune and inflammatory cells. Blood 2014; 123: 2759-2767.

78 Rondina MT, Garraud O. Emerging evidence for platelets as immune and inflammatory effector cells. Front Immunol 2014; 5: 653.

79 Zarbock A, Polanowska-Grabowska RK, Ley K. Plateletneutrophil-interactions: linking hemostasis and inflammation. Blood Rev 2007; 21: 99-111.

80 Li J, Kim K, Barazia A, Tseng A, Cho J. Platelet-neutrophil interactions under thromboinflammatory conditions. Cell Mol Life Sci 2015; 72: 2627-2643.

81 Rossaint J, Zarbock A. Platelets in leucocyte recruitment and function. Cardiovasc Res 2015; 107: 386-395.

82 Siegel-Axel DI, Gawaz M. Platelets and endothelial cells. Semin Thromb Hemost 2007; 33: 128-135.

83 Henn V, Slupsky JR, Grafe M, Anagnostopoulos I, Forster R, Muller-Berghaus $\mathrm{G}$ et al. CD40 ligand on activated platelets triggers an inflammatory reaction of endothelial cells. Nature 1998; 391: 591-594.

84 Danese S, Scaldaferri F, Papa A, Pola R, Gasbarrini A, Sgambato A et al. CD40L-positive platelets induce CD40L expression de novo in endothelial cells: adding a loop to microvascular inflammation. Arterioscler Thromb Vasc Biol 2004; 24: e162.

$85 \mathrm{Kim}$ JK, Jeon JS, Kim JW. Correlation between abnormal platelet count and respiratory viral infection in patients from Cheonan, Korea. J Clin Lab Anal 2014.

86 Gao HN, Lu HZ, Cao B, Du B, Shang H, Gan JH et al. Clinical findings in 111 cases of influenza A (H7N9) virus infection. New Engl J Med 2013; 368: 2277-2285.

87 Lopez-Delgado JC, Rovira A, Esteve F, Rico N, Manez Mendiluce R, Ballus Noguera J et al. Thrombocytopenia as a mortality risk factor in acute respiratory failure in H1N1 influenza. Swiss Med Wkly 2013; 143: w13788.

88 Rondina MT, Brewster B, Grissom CK, Zimmerman GA, Kastendieck $\mathrm{DH}$, Harris ES et al. In vivo platelet activation in critically ill patients with primary 2009 influenza A(H1N1). Chest 2012; 141: 1490-1495.

89 Khoufache K, Berri F, Nacken W, Vogel AB, Delenne M, Camerer E et al. PAR 1 contributes to influenza A virus pathogenicity in mice. J Clin Invest 2013; 123: 206-214.

90 Sugiyama MG, Gamage A, Zyla R, Armstrong SM, Advani S, Advani A et al. Influenza virus infection induces platelet-endothelial adhesion which contributes to lung injury. J Virol 2015; 90: 1812-1823.

91 Mazur I, Wurzer WJ, Ehrhardt C, Pleschka S, Puthavathana P, Silberzahn $\mathrm{T}$ et al. Acetylsalicylic acid (ASA) blocks influenza virus propagation via its NF-kappaB-inhibiting activity. Cell Microbiol 2007; 9: 1683-1694.

92 Starko KM. Salicylates and pandemic influenza mortality, 1918-1919 pharmacology, pathology, and historic evidence. Clin Infect Dis 2009; 49: 1405-1410.

93 Eyers S, Weatherall M, Shirtcliffe P, Perrin K, Beasley R. The effect on mortality of antipyretics in the treatment of influenza infection: systematic review and meta-analysis. $J R$ Soc Med 2010; 103: 403-411.

94 Higgins JP, Thompson SG, Deeks JJ, Altman DG. Measuring inconsistency in meta-analyses. BMJ 2003; 327: 557-560.

95 Yang Y, Sun R, Yang H, Zheng F, Gong F. -308 G > A of TNF-alpha gene promoter decreases the risk of multiple sclerosis: a meta-analysis. Mult Scler 2011; 17: 658-665.

96 Sunden Y, Park CH, Matsuda K, Anagawa A, Kimura T, Ochiai K et al. The effects of antipyretics on influenza virus encephalitis in mice and chicks. J Vet Med Sci 2003; 65: 1185-1188.

97 Davis LE, Green CL, Wallace JM. Influenza B virus model of Reye's syndrome in mice: the effect of aspirin. Ann Neurol 1985; 18: 556-559.

98 Crocker JF, Digout SC, Lee SH, Rozee KR, Renton K, Field CA et al. Effects of antipyretics on mortality due to influenza $B$ virus in a mouse model of Reye's syndrome. Clin Invest Med 1998; 21: 192-202.

99 Bouwman JJ, Visseren FL, Bosch MC, Bouter KP, Diepersloot RJ. Procoagulant and inflammatory response of virus-infected monocytes. Eur J Clin Invest 2002; 32: 759-766.

100 Heemskerk JW, Bevers EM, Lindhout T. Platelet activation and blood coagulation. Thromb Haemost 2002; 88: 186-193.

101 Smiley ST, King JA, Hancock WW. Fibrinogen stimulates macrophage chemokine secretion through toll-like receptor 4. J Immunol 2001; 167: 2887-2894.

102 Szaba FM, Smiley ST. Roles for thrombin and fibrin(ogen) in cytokine/chemokine production and macrophage adhesion in vivo. Blood 2002; 99: 1053-1059.

103 Geisbert TW, Hensley LE, Jahrling PB, Larsen T, Geisbert JB, Paragas $\mathrm{J}$ et al. Treatment of Ebola virus infection with a recombinant inhibitor of factor VIla/tissue factor: a study in rhesus monkeys. Lancet 2003; 362: 1953-1958.

104 Antoniak S, Owens AP 3rd, Baunacke M, Williams JC, Lee RD, Weithauser $A$ et al. PAR-1 contributes to the innate immune response during viral infection. J Clin Invest 2013; 123: 1310-1322.

105 Khoufache K, LeBouder F, Morello E, Laurent F, Riffault S, AndradeGordon $\mathrm{P}$ et al. Protective role for protease-activated receptor-2 against influenza virus pathogenesis via an IFN-gamma-dependent pathway. J Immunol 2009; 182: 7795-7802.

106 Nhu QM, Shirey K, Teijaro JR, Farber DL, Netzel-Arnett S, Antalis TM et al. Novel signaling interactions between proteinase-activated receptor 2 and Toll-like receptors in vitro and in vivo. Mucosal Immunol 2010; 3: 29-39.

107 Delvaeye M, Conway EM. Coagulation and innate immune responses: can we view them separately? Blood 2009; 114: 2367-2374.

108 Jackson CJ, Xue M. Activated protein C-an anticoagulant that does more than stop clots. Int J Biochem Cell Biol 2008; 40: 2692-2697.

109 Okajima K. Regulation of inflammatory responses by natural anticoagulants. Immunol Rev 2001; 184: 258-274.

110 Bernard GR, Vincent JL, Laterre PF, LaRosa SP, Dhainaut JF, Lopez-Rodriguez A et al. Efficacy and safety of recombinant human activated protein C for severe sepsis. New Engl J Med 2001; 344: 699-709.

111 Nick JA, Coldren CD, Geraci MW, Poch KR, Fouty BW, O'Brien J et al. Recombinant human activated protein $C$ reduces human endotoxin-induced pulmonary inflammation via inhibition of neutrophil chemotaxis. Blood 2004; 104: 3878-3885.

112 Toltl LJ, Swystun LL, Pepler L, Liaw PC. Protective effects of activated protein C in sepsis. Thromb Haemost 2008; 100 . 582-592.

113 Pestana D, de la Oliva P. Nebulized activated protein C in a paediatric patient with severe acute respiratory distress syndrome secondary to H1N1 influenza. Br J Anaesth 2011; 107: 818-819.

114 Schouten M, de Boer JD, van der Sluijs KF, Roelofs JJ, van't Veer C, Levi $\mathrm{M}$ et al. Impact of endogenous protein $\mathrm{C}$ on pulmonary coagulation and injury during lethal H1N1 influenza in mice. Am J Respir Cell Mol Biol 2011; 45: 789-794.

115 Schouten M, Sluijs KF, Gerlitz B, Grinnell BW, Roelofs JJ, Levi MM et al. Activated protein $\mathrm{C}$ ameliorates coagulopathy but does not influence outcome in lethal H1N1 influenza: a controlled laboratory study. Crit Care 2010; 14: R65.

116 Allen KS, Sawheny E, Kinasewitz GT. Anticoagulant modulation of inflammation in severe sepsis. World J Crit Care Med 2015; 4: 105-115. 
117 Margetic S. Inflammation and haemostasis. Biochem Med 2012; 22: 49-62.

118 Ostrovsky L, Woodman RC, Payne D, Teoh D, Kubes P. Antithrombin III prevents and rapidly reverses leukocyte recruitment in ischemia/ reperfusion. Circulation 1997; 96: 2302-2310.

119 Mizutani A, Okajima K, Uchiba M, Isobe H, Harada N, Mizutani S et al. Antithrombin reduces ischemia/reperfusion-induced renal injury in rats by inhibiting leukocyte activation through promotion of prostacyclin production. Blood 2003; 101: 3029-3036.

120 Congote LF. The C-terminal 26-residue peptide of serpin A1 is an inhibitor of HIV-1. Biochem Biophys Res Commun 2006; 343: 617-622.

121 Elmaleh DR, Brown NV, Geiben-Lynn R. Anti-viral activity of human antithrombin III. Int J Mol Med 2005; 16: 191-200.

122 Whitney JB, Asmal M, Geiben-Lynn R. Serpin induced antiviral activity of prostaglandin synthetase-2 against HIV-1 replication. PLoS One 2011; 6: e18589.

123 Quenelle DC, Hartman TL, Buckheit RW, Prichard MN, Lynn RG. Anti-HSV activity of serpin antithrombin III. Int Trends Immun 2014; 2: 87-92.

124 Asmal M, Seaman M, Lin W, Chung RT, Letvin NL, Geiben-Lynn R. Inhibition of HCV by the serpin antithrombin III. Virol J 2012; 9: 226.

125 Smee DF, Hurst BL, Day CW, Geiben-Lynn R. Influenza Virus H1N1 inhibition by serine protease inhibitor (serpin) antithrombin III. Int Trends Immun 2014; 2: 83-86.

126 Bahgat MM, Blazejewska P, Schughart K. Inhibition of lung serine proteases in mice: a potentially new approach to control influenza infection. Virol J 2011; 8: 27.

127 Peraramelli S, Rosing J, Hackeng TM. TFPI-dependent activities of protein S. Thromb Res 2012; 129(Suppl 2): S23-S26.

128 Wang Y, Chen J, Ling M, Lopez JA, Chung DW, Fu X. Hypochlorous acid generated by neutrophils inactivates ADAMTS13: an oxidative mechanism for regulating ADAMTS13 proteolytic activity during inflammation. J Biol Chem 2015; 290: 1422-1431.

129 Schwameis M, Schorgenhofer C, Assinger A, Steiner MM, Jilma B. VWF excess and ADAMTS13 deficiency: a unifying pathomechanism linking inflammation to thrombosis in DIC, malaria, and TTP. Thromb Haemost 2015; 113: 708-718.

130 Draxler DF, Medcalf RL. The fibrinolytic system-more than fibrinolysis? Transfus Med Rev 2015; 29: 102-109.

131 Cesarman-Maus G, Hajjar KA. Molecular mechanisms of fibrinolysis. Br J Haematol 2005; 129: 307-321.

132 Godier A, Hunt BJ. Plasminogen receptors and their role in the pathogenesis of inflammatory, autoimmune and malignant disease. J Thromb Haemost 2013; 11: 26-34.

133 Syrovets $\mathrm{T}$, Lunov 0 , Simmet T. Plasmin as a proinflammatory cell activator. J Leukoc Biol 2012; 92: 509-519.

134 LeBouder F, Morello E, Rimmelzwaan GF, Bosse F, Pechoux C, Delmas $B$ et al. Annexin II incorporated into influenza virus particles supports virus replication by converting plasminogen into plasmin. J Virol 2008; 82: 6820-6828.

135 Goto H, Kawaoka Y. A novel mechanism for the acquisition of virulence by a human influenza A virus. Proc Natl Acad Sci USA 1998; 95: 10224-10228.

136 Goto H, Wells K, Takada A, Kawaoka Y. Plasminogen-binding activity of neuraminidase determines the pathogenicity of influenza $A$ virus. J Virol 2001; 75: 9297-9301.

137 Murakami M, Towatari T, Ohuchi M, Shiota M, Akao M, Okumura Y et al. Mini-plasmin found in the epithelial cells of bronchioles triggers infection by broad-spectrum influenza $A$ viruses and Sendai virus. Eur J Biochem 2001; 268: 2847-2855.
138 Yao D, Kuwajima M, Kido H. Pathologic mechanisms of influenza encephalitis with an abnormal expression of inflammatory cytokines and accumulation of mini-plasmin. J Med Invest 2003; 50: 1-8.

139 Yao D, Chen Y, Kuwajima M, Shiota M, Kido H. Accumulation of mini-plasmin in the cerebral capillaries causes vascular invasion of the murine brain by a pneumotropic influenza $A$ virus: implications for influenza-associated encephalopathy. Biol Chem 2004; 385: 487-492.

140 LeBouder F, Lina B, Rimmelzwaan GF, Riteau B. Plasminogen promotes influenza A virus replication through an annexin 2dependent pathway in the absence of neuraminidase. J Gen Virol 2010; 91(Pt 11): 2753-2761.

141 Sun X, Tse LV, Ferguson AD, Whittaker GR. Modifications to the hemagglutinin cleavage site control the virulence of a neurotropic H1N1 influenza virus. J Virol 2010; 84: 8683-8690.

142 Tse LV, Marcano VC, Huang W, Pocwierz MS, Whittaker GR. Plasmin-mediated activation of pandemic H1N1 influenza virus hemagglutinin is independent of the viral neuraminidase. J Virol 2013; 87: 5161-5169.

143 Tse LV, Whittaker GR. Modification of the hemagglutinin cleavage site allows indirect activation of avian influenza virus H9N2 by bacterial staphylokinase. Virology 2015; 482: 1-8.

144 Berri F, Rimmelzwaan GF, Hanss M, Albina E, Foucault-Grunenwald $\mathrm{ML}$, Le VB et al. Plasminogen controls inflammation and pathogenesis of influenza virus infections via fibrinolysis. PLoS Pathog 2013; 9: e1003229.

145 Yasar Yildiz S, Kuru P, Toksoy Oner E, Agirbasli M. Functional stability of plasminogen activator inhibitor-1. ScientificWorldJournal 2014; 2014: 858293.

146 Dittmann M, Hoffmann HH, Scull MA, Gilmore RH, Bell KL, Ciancanelli $\mathrm{M}$ et al. A serpin shapes the extracellular environment to prevent influenza A virus maturation. Cell 2015; 160: 631-643.

147 Visseren FL, Verkerk MS, Bouter KP, Diepersloot RJ, Erkelens DW. Interleukin-6 production by endothelial cells after infection with influenza virus and cytomegalovirus. J Lab Clin Med 1999; 134: 623-630.

148 Bhandary YP, Shetty SK, Marudamuthu AS, Midde KK, Ji HL, Shams $\mathrm{H}$ et al. Plasminogen activator inhibitor-1 in cigarette smoke exposure and influenza A virus infection-induced lung injury. PLoS One 2015; 10: e0123187.

149 Rynda-Apple A, Robinson KM, Alcorn JF. Influenza and bacterial superinfection: illuminating the immunologic mechanisms of disease. Infect Immun 2015; 83: 3764-3770.

150 McCullers JA. The co-pathogenesis of influenza viruses with bacteria in the lung. Nat Rev Microbiol 2014; 12: 252-262.

151 McCullers JA. Insights into the interaction between influenza virus and pneumococcus. Clin Microbiol Rev 2006; 19: 571-582.

152 Schuliga M. The inflammatory actions of coagulant and fibrinolytic proteases in disease. Mediators Inflamm 2015; 2015: 437695.

153 Zelaya H, Tsukida K, Chiba E, Marranzino G, Alvarez S, Kitazawa H et al. Immunobiotic lactobacilli reduce viral-associated pulmonary damage through the modulation of inflammation-coagulation interactions. Int Immunopharmacol 2014; 19: 161-173.

154 Zelaya H, Tada A, Vizoso-Pinto MG, Salva S, Kanmani P, Aguero G et al. Nasal priming with immunobiotic Lactobacillus rhamnosus modulates inflammation-coagulation interactions and reduces influenza virus-associated pulmonary damage. Inflamm Res 2015; 64: 589-602.

155 Zhirnov OP, Klenk HD, Wright PF. Aprotinin and similar protease inhibitors as drugs against influenza. Antiviral Res 2011; 92: 27-36. 